\title{
Hans R. Held, Founder of ORCA
}

3rd December 1998, Dr. Hans R. Held, the founder of ORCA, died in Geneva at the age of 89. Many younger ORCA members do not know more about him than his name.

Born in 1910, Hans Held, after his military service, finished his dentistry studies in the 1930s and started a promising carreer as a research worker and teacher at the Dental School of the Universtiy of Geneva. The Second World War ended this carreer abruptly, and a serious task was awaiting the young army officer. He was in charge of organizing mobile dental surgery units in the complex Swiss mountain military defence system, no easy task in a country with a pre-war road network and border threats from north, south, east, and west. He fulfilled this task brilliantly.

After the war, European university life, scientific knowledge and technology were in a desolate, rudimentary state, and publications in US American dental journals had not been read for nearly a decade. In this situation Hans Held did not return to the University, but kept his kenn interest in dental science. Although he was busy in his dental office in Geneva, he studied the literature and was fascinated by the preventive impact of water-borne fluoride. While the Americans focussed on implementing fluoridation of drinking water, Hans Held was aware of the differences in mentality, culture and readiness to accept innovations between Europe and the New World.

He conceived the idea of developing tablets with fluoride in a form which would simulate the caries-preventive effect of fluoride in drinking water. He dedicated part of his time to doing research into the assumed interaction and antagonism between fluoride and iodium to which critics attributed a risk of thyroid dysfunction. His results showed that this argument against fluoride administration was not valid, but he at the same time realized that he could not do the research necessary for a European alternative for water fluoridation on his own. There was no center for the study of fluoride physiology, and therefore Hans Held in 1953 founded an organization for research into fluoride action and caries prevention: 'Organisme Européen sur la recherche du fluor et de la carie dentaire', abbreviated ORCA.

The organization did not have a very quick start because in the first years it attracted more enthusiastic dental practitioners than knowledgeable scientists. However, Hans Held succeeded in interesting more and more chemists, biochemists, microbiologists, and crystallographers in the topic: Otto Trautz, Fritz Bramstedt, Otto Backer Dirks, Neil Jenkins, Leon Singer, Wallace Armstrong, Finn Brudevold, and many others.

Hans Held has served ORCA successively as President, as its long-standing Secretary General, as Co-editor of the Proceedings preceding our Journal, Caries Research, as Treasurer and its Legal Representative in Switzerland where ORCA is still officially residing.

Although illness during the last 12 years of his life stopped Hans Held from attending ORCA meetings, he kept a keen interest in the activities and success stories of the members. Moreover, up until a few months before his death, he managed to stay active as scientific adviser of firms developing toothpastes and toothbrushes, and he kept in touch with his old ORCA friends. Hans Held will remain to be remembered as a pioneer in fluoride research and prevention of dental caries.

Klaus G. König

\begin{tabular}{ll}
\hline KARGER & ○ 1999 S.Karger AG, Basel \\
Fax +41 61 306 12 34 & 0008-6568/99/0334-0251 \$17.50/0 \\
$\begin{array}{l}\text { E-Mail karger@karger.ch } \\
\text { www.karger.com }\end{array}$ & $\begin{array}{l}\text { Accessible online at: } \\
\text { http://BioMedNet.com/karger }\end{array}$
\end{tabular}

